\title{
Influence of 1,4-butanediol on Hydroxyl-Terminated Poly(butadiene) Based Composite Propellant Binder Characteristics
}

\author{
Saša Brzić ${ }^{1)}$ \\ Vesna Rodić ${ }^{1)}$ \\ Mirjana Dimić ${ }^{1)}$ \\ Danica Simic ${ }^{1)}$ \\ Ljiljana Jelisavac ${ }^{1)}$ \\ Marica Bogosavljević ${ }^{1)}$
}

\begin{abstract}
1,4-butanediol, as a chain extender, was incorporated into a hydroxyl-terminated poly(butadiene) based composite rocket propellant binder composition. As curing agents, isophorone diisocyanate (IPDI) and toluene diisocyanate (TDI) were used. Composite propellant binder network and mechanical properties, influenced by a presence of 1,4-butanediol, were examined. Network characteristics, sol-gel content and crosslink density have been calculated and successfully correlated to the mechanical uniaxial tensile properties of the tested propellant binders. Differential scanning calorimetry studies showed that 1,4-butanediol content did not influence the glass transition temperature, however the uniaxial tensile properties were shown to be a function of the crosslink density
\end{abstract}

Key words: butanediol, hydroxyl-terminated polybutadiene, composite rocket propellant fuel, propellant binder component, mechanical properties.

\section{Introduction}

$\mathrm{C}$ OMPOSITE propellants are a mixture of powdered solid particles of inorganic oxidizer, such as ammonium perchlorate (AP), metallic fuel, such as aluminum powder, and/or other solids and additives (plasticizer, antioxidant, and bonding agent), embedded in and held together by an elastomeric matrix that imparts rubber-like elasticity to the propellant grains [1]. The elastomer based matrix serves both as a fuel component and as a binder between the energetic particles, providing the necessary mechanical properties to prevent break-up of the grains or crack formation during ignition or combustion [2]. Once cured, the binder makes the propellant flexible, which decreases the probability of fractures in propellant under stress and pressure. Being a viscoelastic material, solid rocket propellant mechanical properties are highly dependent on temperature and strain rate. Thus, they degrade over time due to chemical aging and damage accumulation, so they have a limited lifetime. The appearance of the fracture of the rocket motor propellant due to different loads acting from the moment of production and continuously during the storage and use, might lead to the undesirable changes in working mode or to the rocket motor explosion [3]. In order to meet the increasing demands of various working environments, the viscoelastic properties of hydroxyl-terminated poly(butadiene) based composite rocket propellants have been thoroughly examined in previuos papers [4], with a particular attention to the effects of additives and solid fillers in these properties $[5,6]$.

The composite propellant binder comprises at least two components. The first one is a liquid prepolymer and the second one is a curing agent. Polyurethane-based binder systems (hydroxyl-functional prepolymers, such as hydroxylterminated polybutadiene, HTPB, cured using multifunctional isocyanates) are extensively used in composite solid propellants, due to convenient reaction conditions and relative lack of adverse side reactions [7]. An essential requirement in the selection of a particular polymeric component is that it must exhibit good mechanical properties. In fact, the major cause of a failure in solid rocket motors is linked to the structural integrity of the propellant [8]. Therefore, the use of different types of polyurethanes is typical for the abovementioned applications because of the alternating hard and soft segments within their structure [9].

The tensile mechanical properties of a composite propellant depend mainly on the tensile properties of the binder. The ultimate mechanical properties of the binder can be tailored by varying the R-value (equivalents of NCO groups/equivalents of $\mathrm{OH}$ groups). Increasing the tensile strength should not be done at the expense of the ultimate elongation, as occurs when the crosslinks density in HTPB is increased by increasing isocyanate/hydroxyl $(\mathrm{NCO} / \mathrm{OH})$ equivalent ratio. The ammount of urethane bonds can be increased by adding low molecular weight diols to the polymer. These types of diols are called "chain extenders". The most common aliphatic diol for this purpose is 1,4butanediol (1,4-BD) [10]. The tensile mechanical characteristics of HTPB have been modified by increasing the hard segment content, while 1,4-BD is used as a chain extender. The materials were crosslinked with either 1,6hexamethylene diisocyanate or dicyclohexylmethane 4,4'-

\footnotetext{
1) Military Technical Institute (VTI), Ratka Resanovića 1, 11132 Belgrade, SERBIA

Correspondence to: Saša Brzić; e-mail: sasabrzic@gmail.com
} 
diisocyanate. The results showed that the tensile strength strongly increases with the addition of up to two moles of diol per mole HTPB [11].

In this work, the polymer network and mechanical properties of HTPB/1,4-BD cured with aliphatic (IPDI) and aromatic (TDI) diisocyanates were examined. The main goal was to analyze the influence of the 1,4-butanediol content on the composite propellant binder physico-chemical and mechanical properties, i.e. the dependence of mechanical properties on the binder crosslinking density.

\section{Experimental part}

\section{Materials}

Eight composite propellant binder compositions (Table 1) selected for this study consisted of $100 \mathrm{phr}$ of HTPB (R-45HT, Sartomer, viscosity at $23^{\circ} \mathrm{C}: 8000 \mathrm{mPas}, \mathrm{OH}$ value: $47.12 \mathrm{mg}$ $\mathrm{KOH} / \mathrm{g}$, hydroxyl functionality: 2.4 - 2.6, average molecular weight: $2800 \mathrm{~g} / \mathrm{mol}$, specific gravity at $23^{\circ} \mathrm{C}: 0.901 \mathrm{~g} / \mathrm{cm}^{3}$, glass transition temperature, $T_{\mathrm{g}}:-76^{\circ} \mathrm{C}$ ) and $2.5 \mathrm{phr}$ of antioxidant (2,2'-methylene-bis-(4-methyl-6-tertbutylphenol), which is commercially available as a product called AO-2246; Fluka AG, Switzerland). Tested binder samples differed from each other in a 1,4-BD content (average molecular weight: $90.12 \mathrm{~g} / \mathrm{mol}, \mathrm{OH}$ Value: $1245 \mathrm{mg} \mathrm{KOH} / \mathrm{g}, T_{\mathrm{g}}$ : $-42^{\circ} \mathrm{C}$ ). Ingredients mix ratio is expressed by phr (parts per hundred resin based on 100 parts of HTPB).

Curing occurs when the hydroxyl groups of the prepolymer (HTPB) react with the isocyanate groups of the curing agent (IPDI, TDI, purity: 98\%, Sigma Aldrich, Germany) to form urethane crosslinks (Fig.1).

HTPB

TDI

$\mathrm{HO}+\mathrm{CH}_{2}-\mathrm{CH}=\mathrm{CH}-\mathrm{CH}_{2} t_{\mathrm{n}}{ }^{+}{ }^{\mathrm{NCOH}}$

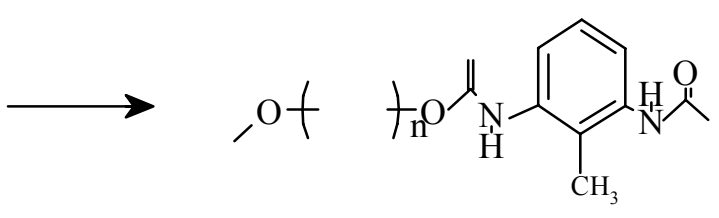

Figure 1. Schema of the urethane reaction

The $\mathrm{NCO} / \mathrm{OH}$ ratio between the isocyanate groups of the curing agent to the hydroxyl groups of the prepolymer was 0.85 . The tested composite propellant binder formulations were mixed in a 1.51 DRAIS FH planetary mixer at the temperature of $60^{\circ} \mathrm{C}$. All of the binder ingredients, except the curing agent, were blended thoroughly for 15 minutes at the ambient pressure and then vacuum mixed for another 15 minutes. Then, the curing agent was added to the mixture, mixed for 10 minutes at the ambient pressure and then vacuum mixed for another 10 minutes. Finally, the mixture was cast and cured into the teflon-coated metal plates to form $4 \mathrm{~mm}$ thick slabs. The curing was performed for 5 days at $70^{\circ} \mathrm{C}$.

Compositions $\mathrm{CPB} 0$ and $\mathrm{CPB} 00$ are the baseline propellant binder compositions containing no 1,4-BD, with IPDI and TDI as a curing agent, respectively. $1,4-\mathrm{BD}$ content $(\zeta)$ varied from 1 to 3 moles per mole of prepolymer.
Table 1. Tested propellant binder compositions

\begin{tabular}{|c|c|c|c|c|c||}
\hline \multirow{2}{*}{ Sample } & \multirow{2}{*}{$\zeta,[\mathrm{mol}]$} & \multicolumn{5}{|c|}{ Ingredient [phr] } \\
\cline { 3 - 6 } & R45HT & IPDI & TDI & $1,4-\mathrm{BD}$ \\
\hline \hline CPB0 & - & 100 & 8.14 & - & - \\
\hline CPB01 & 1 & 100 & 15.14 & - & 3.22 \\
\hline CPB02 & 2 & 100 & 21.87 & - & 6.44 \\
\hline CPB03 & 3 & 100 & 28.61 & - & 9.66 \\
\hline CPB00 & - & 100 & - & 6.31 & - \\
\hline CPB11 & 1 & 100 & - & 11.01 & 3.22 \\
\hline CPB22 & 2 & 100 & - & 15.71 & 6.44 \\
\hline CPB33 & 3 & 100 & - & 20.41 & 9.66 \\
\hline
\end{tabular}

Methods

Determination of the network density of the composite propellant binder samples

The network density of the cured propellant binder samples was estimated by a degree of swelling by an appropriate solvent at equilibrium [12]. As solvent, toluen was used. Swelling test was carried out on the specimens length of 20 $\mathrm{mm}$, width of $20 \mathrm{~mm}$ and thickness of $3 \mathrm{~mm}$ at the $T=25^{\circ} \mathrm{C}$. In the preliminary experiment, the sample was allowed to swell for 4 days, but the weight became constant after two days, indicating that equilibrium is reached. In this study, the binder samples were swelled for two days.

Sol-Gel measurements

The sol content of the propellant binder $\left(S_{\text {poly }}\right)$ is the weight fraction of the propellant, which is obtained by the extraction with the solvent, as described in STANAG 4581 [13]. The extraction was carried out in three Soxhlet extraction units (refluxing with solvent) for 16 hours with approximatelly $150 \mathrm{ml}$ of dichloromethane $\left(\mathrm{CH}_{2} \mathrm{Cl}_{2}\right)$ each.

Uniaxial tensile properties of the composite propellant binder samples

The uniaxial tensile properties of the cured propellant binder samples were evaluated at $20^{\circ} \mathrm{C}$ using the INSTRON 1122 tensile test machine fitted with a $5000 \mathrm{~N}$ load cell. «JANNAF C» dog bone samples (120.65 mm length, $25 \mathrm{~mm}$ width, $8 \mathrm{~mm}$ thickness) were used. Crosshead speed of the tensile machine was $50 \mathrm{~mm} / \mathrm{min}$, while the effective gauge length of the JANNAF C samples was $68.6 \mathrm{~mm}$.

Differential scanning calorimetry (DSC)

DSC analyses were carried out using the DSC Q20 manufactured by TA Instruments with a liquid nitrogen cooling. The temperature scale is calibrated using the melting temperature of a high purity indium. These measurements were made with the purpose to investigate the thermal based glass transition temperature $\left(T_{\mathrm{g}}\right)$ of the tested samples. The small amount of the samples $(\sim 5 \mathrm{mg})$ was scanned with a heating rate of $10^{\circ} \mathrm{C} \mathrm{min}^{-1}$, in a range from $-90^{\circ} \mathrm{C}$ to $+50^{\circ} \mathrm{C}$. The $T_{\mathrm{g}}$ of the samples were determined from the midpoints of the transitions.

\section{IR Spectroscopy}

Infrared spectroscopy was performed by using the Perkin Elmer IR spectrometer, spectrum range $4000-200 \mathrm{~cm}^{-1}$. A thin layer of the sample (sol content) was placed on a plate of potassium bromide.

\section{Results}

\section{Composite propellant binder network density}

The gravimetric technique is used for measuring the swell ratio of the crosslinked polymeric propellant binder networks [14]. A sample is carefully weighed $\left(W_{d}\right)$, then immersed in 
toluen as a solvent at the required temperature for 24 hours. At the end of this period, the sample is again carefully weighed $\left(W_{\mathrm{g}}\right)$, and the swell ratio is computed from this and ratio of the densities of the solvent to the polymer, $K$, as

$$
q=\frac{W_{d}+W_{g}-W_{d} \cdot K}{W_{d}}
$$

The density of toluene is $0.86 \mathrm{~g} \mathrm{~cm}^{-3}$, and those of cured binder samples were in the range of 0.927 to $0.971 \mathrm{~g} \mathrm{~cm}^{-3}$ [15].

The network density $\left(N \times 10^{-5}\right.$ molcm $\left.^{-3}\right)$ of the polymer can be estimated by the value of $v_{\mathrm{r}}$ as follows:

$$
\ln \left(1-v_{r}\right)+v_{r}+\chi v_{r}^{2}=-N V_{1}\left(v_{r}^{\frac{1}{3}}-\frac{v_{r}}{2}\right)
$$

where: $V_{\mathrm{r}}$ - volume fraction of the tested binder sample in the swollen gel fraction, $\chi$ - Flory-Huggins polymer-solvent interaction parameter, $V_{1}$ - molar volume of the solvent, $N$ network density of the tested binder sample.

Knowing soluble fraction content $\left(S_{\text {poly }}\right)$, the crosslink density $(C)$ of the propellant binder (Table 3 ) can also be estimated by following the modified version of the CharlesbyPinner [16] equation

$$
C=\frac{\left(1-S_{\text {poly }}\right) \cdot\left(2-\left(S_{\text {poly }}+\sqrt{S_{\text {poly }}}\right)\right)}{\left(S_{\text {poly }}+\sqrt{S_{\text {poly }}}\right)}
$$

The crosslink densities obtained in this manner for various 1,4-BD levels are compared with the corresponding values obtained using the swelling test (Fig.2).
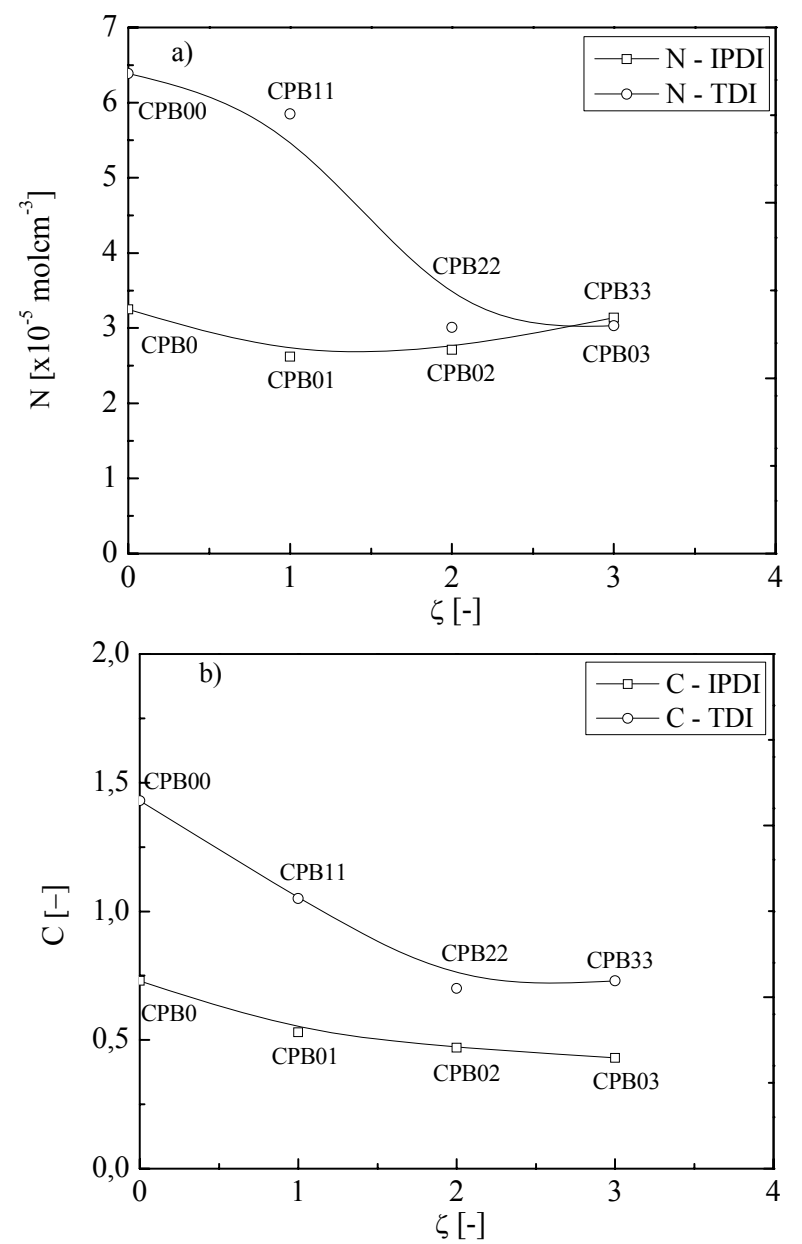

Figure 2. Crosslink density values dependencies on 1,4-BD content obtained by a) a swell method and b) a sol-gel analysis
The soluble or extractable content is a useful parameter to characterize the extent of cross-linking within a cross-linked polymer [17]. The greater the fraction of not cross-linked polymer chains, the higher is the soluble fraction. Both $\mathrm{N}$ and $\mathrm{C}$ values are higher for the propellant binder compositions containing TDI as a curing agent. The baseline formulations, containing TDI and IPDI (CPB0 and CPB00), have the higher soluble fraction values, whereas the formulation containing 1,4-BD are characterized by higher $S_{\text {poly }}$ content and lower cross-link density values. Decrease of the network density can be explained by an increase in physical crosslinking due to a high concentration of the linear 1,4-BD polymer chains.

The parameters obtained by a sol-gel analysis are very useful and will be used for correlation with the results obtained by a mechanical characterization.

\section{DSC measurements}

As an essential ingredient, the binder largely determines the mechanical properties of the composite solid propellants. Low glass transition temperature is preferred for the composite propellant binder, so that it can withstand a large spectrum of stress transients in an operation. Therefore, the glass transition temperature $\left(T_{\mathrm{g}}\right)$ of the elastomer bonded composite propellant is one of the most important property determining their in-service application [18]. $T_{\mathrm{g}}$ values of the tested propellant binder samples determined through DSC are shown in Table 2.

Table 2. Glass transition temperature values of the tested propellant binder samples

\begin{tabular}{|c|c|}
\hline Sample & $T_{\mathrm{g}},\left[{ }^{\circ} \mathrm{C}\right]$ \\
\hline \hline CPB0 & -73.41 \\
\hline CPB01 & -73.68 \\
\hline CPB02 & -73.14 \\
\hline CPB03 & -71.48 \\
\hline CPB00 & -72.97 \\
\hline CPB11 & -73.15 \\
\hline CPB22 & -73.28 \\
\hline CPB33 & -73.07 \\
\hline
\end{tabular}

Polyurethane based elastomers contain soft and rigid segments [10]. The soft segments consist of large flexible non-crystalline polymer chains, while the rigid segments consist of diisocyanate residues, chain extenders and urethane groups. Glass transition as a relaxation process involves the release of the cooperative motions of HTPB prepolymer main chains between the crosslinks within the soft segment regions. These polymer network segments are flexible at the room temperature because of the urethane group's low polarity.

The differences between $T_{\mathrm{g}}$ values of the tested binder samples determined through DSC are within an experimental error. Obtained $T_{\mathrm{g}}$ values show that any regularity cannot be observed in its change with increasing 1,4-BD content in the propellant binder formulations. Also, the values are lower than the minimum service temperature (usually -40 to $-50{ }^{\circ} \mathrm{C}$, depending on the application). The $T_{\mathrm{g}}$ of HPTB cured with IPDI determined by DSC is higher than that of IPDI cured HTPB (reported as $-83^{\circ} \mathrm{C}$ by Bhagawan et al. [19]). Thus, 1,4$\mathrm{BD}$ has very little influence on the glass transition temperature, which may be due to the fact that for the elastomers, glass transition temperature depends more on segmental motion of the polymer chains than on the concentration of crosslink points [20]. This indicates that, for the tested propellant binder networks, the distance between the crosslink points is such that any reduction in local 
constraints caused by a presence of the 1,4-BD during crosslinking does not affect $T_{g}$.

\section{Uniaxial tensile mechanical characteristics}

The uniaxial tensile mechanical properties: tensile strength $\left(\sigma_{\mathrm{m}}\right)$, strain at maximum load $\left(\varepsilon_{m}\right)$, strain at break $\left(\varepsilon_{b}\right)$ and the Young's modulus $(E)$ for the tested propellant binder samples are shown in Table 3. Because of the different structures of used curing agents, the measured tensile mechanical properties are a function of the original polymer matrix structure, also of the secondary bonds formed in the polymer. Considering the baseline binder compositions, the results revealed that TDI based propellant binders have higher stress and lower strain at the maximum load compared to one with IPDI. This behaviour is caused by the TDI's stiff and rigid benzene ring, which is absent in IPDI.

Table 3. Uniaxial tensile properties as a function of 1,4-butanediol content and crosslink density

\begin{tabular}{|c|c|c|c|c|c||}
\hline Sample & $\begin{array}{c}\zeta, \\
{[\mathrm{mol}]}\end{array}$ & $\begin{array}{c}C, \\
{[-]}\end{array}$ & $\begin{array}{c}\sigma_{\mathrm{m}}, \\
{[\mathrm{MPa}]}\end{array}$ & $\begin{array}{c}\varepsilon_{\mathrm{m}}, \\
{[\%]}\end{array}$ & $\begin{array}{c}E, \\
{[\mathrm{MPa}]}\end{array}$ \\
\hline \hline CPB0 & - & 0.73 & 0.29 & 663.77 & 0.15 \\
\hline CPB01 & 1 & 0.54 & 0.29 & 623.15 & 0.21 \\
\hline CPB02 & 2 & 0.47 & 0.41 & 545.27 & 0.29 \\
\hline CPB03 & 3 & 0.43 & 0.39 & 355.43 & 0.40 \\
\hline CPB00 & - & 1.43 & 0.36 & 277.60 & 0.32 \\
\hline CPB11 & 1 & 1.05 & 0.48 & 525.06 & 0.27 \\
\hline CPB22 & 2 & 0.70 & 0.42 & 814.52 & 0.12 \\
\hline CPB33 & 3 & 0.72 & 0.40 & 718.20 & 0.13 \\
\hline
\end{tabular}

The number of urethane bonds is affected by the choice of the curing agent and the hard segment content $(\xi$, calculated as the mass fraction of 1,4-BD and curing agent in the binder composition) is altered to only a slight extent. Figure 3 shows $\sigma_{m}$ values as a function of a hard segment content. IPDI achieves a similar number of urethane groups as TDI, but due to its cyclic structure the orientation of polymer segments is weaker. This leads to the difficulties in establishing the secondary bonds, weakening the interchain forces and lowering the values of stress at the maximum load.

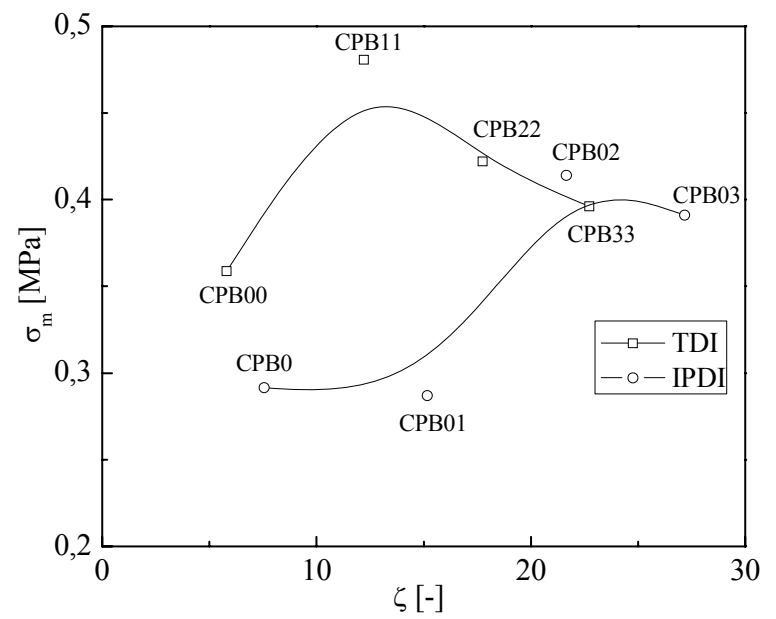

Figure 3. Tensile strength $\left(\sigma_{\mathrm{m}}\right)$ dependence on a hard segment content for the tested propellant binder samples

The level of 1,4-BD ( $\zeta=1$, sample CPB11) contributes to the increase in tensile strength value by $34 \%$ compared to the baseline composition with TDI. Composition CPB02 $(\zeta=2)$ has an increase in this value by $45 \%$. Percentage-wise, this corresponds to an increase in the hard segment content.

The effect of the 1,4-BD on $\varepsilon_{m}$ value of tested binder samples is dependent on the applied curing agent. Considering the $\varepsilon_{m}$ value of the baseline compositions, and the trend of changes, the addition of 1,4-BD contributes to a decrease of the value by $46 \%$ for $\mathrm{CPB} 03(\zeta=3)$, and an increase of $193 \%$ for CPB22 $(\zeta=2)$.

As can be seen, for binder samples containing IPDI as a curing agent, an increase in the modulus is realized at the expense of the decreased $\varepsilon_{m}$ value. The modulus increases linearly with increasing amount of 1,4-BD.

It is evident, for HTPB/TDI binder samples, with a decrease in the crosslink density, the $\varepsilon_{m}$ value increases. Explanation is as follows: incorporation of 1,4-BD into the binder increases the molecular weight of polymer chains between crosslinks, which further increase the $\varepsilon_{m}$ value (Table 3 ). Conversely, for the HTPB/IPDI binder samples, a decrease in the crosslink density also decreases the $\varepsilon_{\mathrm{m}}$ value. The explanation could be as follows: the N-H group in polyurethane could develop a hard segment by hydrogen bonding with the oxygen of carbonyl groups. Such strong hydrogen bonding acts as physical crosslinks restricting the motion of segmental of the polymer chain. So, a significant phase separation occurred between the hard and soft segments and decreased the elasticity of the propellant binder [21].

\section{IR measurements}

Fig. 4 shows the IR spectra of the propellant binders with IPDI as a curing agent, without and with 1,4-butanediol as a chain extender.

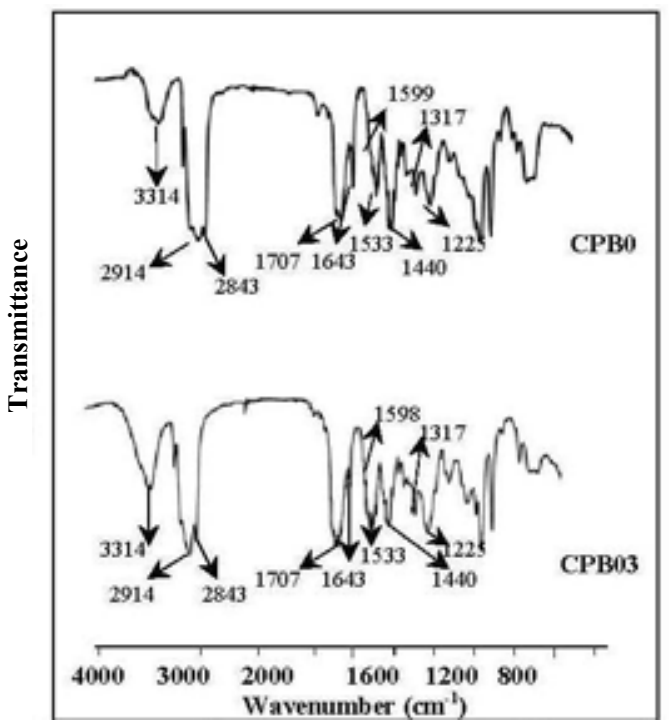

Figure 4. IR spectrum of the propellant binders with IPDI as a curing agent

IR spectra show characteristic bands of the urethane groups at $3314 \mathrm{~cm}-1$ ( $\mathrm{N}-\mathrm{H}$ stretching). The other peaks observed were assigned as: $2914 \mathrm{~cm}^{-1}(\mathrm{CH}$ symmetric stretching vibrations of $\left.\mathrm{CH}_{2}\right) ; 2843 \mathrm{~cm}^{-1}(\mathrm{CH}$ asymmetric stretching vibrations of $\mathrm{CH}_{2}$ groups); $1707 \mathrm{~cm}^{-1}, 1643 \mathrm{~cm}^{-1}(\mathrm{C}=\mathrm{O}$ bond); $1599 \mathrm{~cm}^{-1}$ (NH deformations); $1533 \mathrm{~cm}^{-1}$ (aromatic ring) $1440 \mathrm{~cm}^{-1}$ (CH2 bending vibration); $1317^{\mathrm{cm}-1}$ (CH2 wagging). By extending prepolymer with $1,4-\mathrm{BDO}$, the IR spectra showed a very strong peak at about $1707 \mathrm{~cm}^{-1}$ which was assigned to $\mathrm{C}=\mathrm{O}$ stretching of urethane. Peaks corresponding to the absorption of $\mathrm{NH}, \mathrm{C}=\mathrm{O}$ and $\mathrm{C}-\mathrm{O}$ were observed at $3314 \mathrm{~cm}^{-1}, 1707 \mathrm{~cm}^{-1}$ (non-hydrogen bonded), $1643 \mathrm{~cm}^{-1}$ (hydrogen bonded) and $1225 \mathrm{~cm}^{-1}$, respectively, which indicate the propellant binders with the urethane (NHCOO) group. The observed $\mathrm{N}-\mathrm{H}$ bending vibrations at $1598 \mathrm{~cm}^{-1}$, C-O-C stretching absorption band corresponding to the linkage between $\mathrm{OH}$ and $\mathrm{NCO}$ groups to form an 
urethane bond in the range of $1057-1130 \mathrm{~cm}^{-1}$ also provide a strong evidence for the formation of PU [22].

It is valuable to mention the N-H group in polyurethane could develop a hard segment to hard segment H-bonding with the oxygen of carbonyl groups. Such a strong $\mathrm{H}$ bonding acts as physical crosslink, restricting the motion of the polymer's segments [23].

Fig. 5 shows the IR spectra of the propellant binders with TDI as a curing agent, without and with 1,4-butanediol as a chain extender.

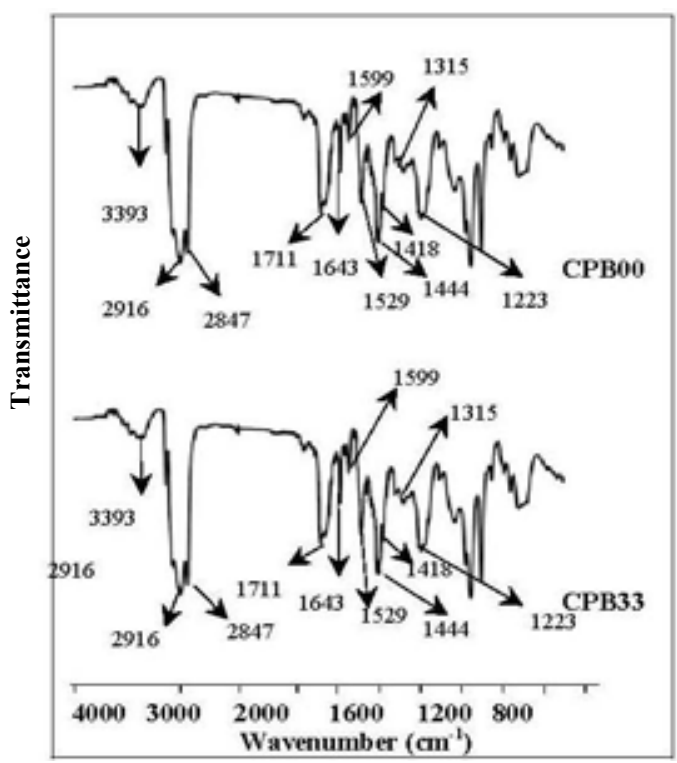

Figure 5. IR spectrum of the propellant binders with TDI as a curing agent

IR spectra show characteristic bands of the urethane groups at $3393 \mathrm{~cm}^{-1}$ (N-H stretching). The other peaks observed are: $2916 \mathrm{~cm}^{-1}$ (symmetric stretching); $2847 \mathrm{~cm}^{-1}$ (asymmetric stretching vibrations of $\mathrm{CH}_{2}$ ) groups; $1711 \mathrm{~cm}^{-1}, 1649 \mathrm{~cm}^{-1}$ ( $\mathrm{C}=\mathrm{O}$ bond); $1599 \mathrm{~cm}^{-1}, 1529 \mathrm{~cm}^{-1}$ (NH deformations); $1444 \mathrm{~cm}^{-1}$ and $1418 \mathrm{~cm}^{-1}$ ( $\mathrm{CH}_{2}$ bending vibration); $1315 \mathrm{~cm}^{-1}$ $\left(\mathrm{CH}_{2}\right.$ wagging). Peaks corresponding to the absorption of $-\mathrm{N}-\mathrm{H}$ and $-\mathrm{C}=\mathrm{O}$ groups at $3393 \mathrm{~cm}^{-1}$ and $1711 \mathrm{~cm}^{-}$, respectively indicate that the propellant binders have -NHCOO (urethane group). Further is evident that a new peak at $1223 \mathrm{~cm}^{-1}$ for NHCO provides a strong evidence for the formation of PU [22].

\section{Conclusion}

Uniaxial tensile mechanical characterization, sol-gel analysis, differential scanning calorimetry and IR measurements were employed together with a gravimetric swell technique method to elucidate the behaviour of the HTPB-based composite propellant binder containing 1,4butanediol as a chain extender. Crosslink density values of the polymer network evaluated by a sol-gel analysis indicates that the specified 1,4-BD level sol fraction of the tested binder sample is 20 to 45 percent. The obtained network densities trend values are similar meaning that with different analytical techniques the same phenomena was investigated and characterized.

Baseline compositions, HTPB cured with IPDI or TDI, gave the propellant binders with a quite different mechanical characteristics. Adding 1,4-BD into the propellant binder composition affects increasing or decreasing the strain at a maximum stress and the Young's modulus, but the influence on a tensile strength cannot be easily recognized. The highest value of the strain at the maximum stress was found in the CPB22 composition (TDI as a curing agent and 2 moles of
1,4-BD per mole of HTPB). The $T_{\mathrm{g}}$ values of the tested binder samples were aproximately $-73^{\circ} \mathrm{C}$, without any influence of 1,4 -BD on this value. In essence, the desired uniaxial tensile properties require the optimum combination of the chain extender and curing agent. From all the shown data, it can be concluded that the composition of the network forming agents can be optimized to achieve the desired uniaxial tensile properties for a specified application.

\section{References}

[1] SHUSSER,M.: Composite Rocket Propellants, Wiley Encyclopedia of Composites, Space Research Corporation, 2012.

2] KUBOTA,N.: Propellants and Explosives, Wiley, 2007, pp.1-509.

[3] GLIGORIJEVIĆ,N.: Strukturna analiza pogonskih punjenja raketnih motora sa čvrstim gorivom, Naučnotehnička Informacija, (Solid Rocket Propellant Grain Structural Analysis), VTI, 2013, Vol. XLIX, No.1, ISSN 1820-3418, ISBN 978-86-81123-59-1

[4] BRZIĆ,J.S., JELISAVAC,N.LJ., GALOVIĆ,R.J., SIMIĆ,M.D., PETKOVIĆ,LJ.J.: Viscoelastic Properties of Hydroxyl-Terminated Poly(butadiene) Based Composite Rocket Propellants, Chem. Ind., 2014, Vol.68, No.4, pp.435-443.

[5] RODIĆ,V., PETRIC,M.: The Effect of Additives on Solid Rocket Propellant Characteristics, Scientific Technical Review, 2004, Vol.LIV, No.3-4, pp.9-14.

[6] BRZIĆ S , RADULOVIĆ,J.: Dynamic-Mechanical Investigation of Cured Filled Polymeric System of Hydroxyl Terminated Poly(Butadiene)/Isophorone Diisocyanate, Scientific Technical Review, ISSN 1820-0206, 2013, Vol.63, No.4, pp.32-39.

[7] AMTOWER,K.P.: U.S. Patent 7, 011, 722 B2, 2006.

[8] SANTGYANI,R., KUMAR,A., KUMAR,A., GUPTA,M.: Optimization of Network forming agents for Different Types of Composite Propellant Grain, Cent. Eur. J. Energ. Mater., 2013, Vol.10, No.3, pp.409-417.

[9] FUENTE, de la J.L., GARCIA, M.F., CERRADA, M.L.: Viscoelastic Behavior in a Hydroxyl-Terminated Polybutadiene Gum and Its Highly Filled Composites: Effect of the Type of Filler on the Relaxation Processes, J. App. Polym. Sci., 2003, Vol.88, pp.1705-1712.

[10] WINGBORG,N.: Improving the Mechanical Properties of Composite Rocket Propellants, master thesis, Royal Institute of Technology, Stockholm, 2004.

[11] OERTEL,G.: Polyurethanes handbook, $2^{\text {nd }}$ Edition, Carl Verlag, Munich, 1994

[12] KOHGA,M.: Viscoelastic Behaviour of Hydroxyl Terminated Polybutadiene Containing Glycerin, J. App. Polym. Sci., 2011, Vol.122, pp.706-713

[13] STANAG 4581 - Explosives, Assessment of Ageing Characteristics of Composite Propellants Containing an Inert Binder, NATO, 2003.

[14] ASTM D2765-95 - Standard Test Methods for Determination of Gel Content and Swell Ratio of Crosslinked Ethylene Plastics, ASTM International, 2001.

[15] MIL-286 B: Measuring the propellant density at Moor balance.

[16] CHARLESBY,A.: Atomic Radiation and Polymers, Pergamon press, Oxford, 1960.

[17] BOHN,M., CERRI,S.: Ageing Behaviour of Composite Rocket Propellant Formulations Investigated by DMA, SGA, and GPC, IMEMT Symposium, Munich, Germany, 2010, pp.1-32.

[18] POPOVIĆ,R.: Inhibitorski materijali na bazi elastomera, Naučnotehnička Informacija, VTI, 1996, No.6.

[19] BHAGAWAN,S.S., PRABHAKARAN,N., RAMA,M., NINAN,N.K.: Viscoelastic Behaviour of Solid Propellants Based on Various Polymeric Binders, Def. Sci. J., 2011, Vol.45, No.1, pp.17-23.

[20] SEKKAR,V., BHAGAWAN,S.: Polyurethanes based on hydroxyl terminated polybutadiene: modeling of network parameters and correlation with mechanical properties, Elsevier Science, 2000, Vol. 41, No.1, pp.6773-6786.

[21] REHMAN-Ur-FAZAL, Synthesis and Characterization of Speciality Polyurethane Elastomers, master thesis, University of agriculture, Faisalabad, 2010.

[22] SHARMA,Y. R.: Elementary Organic Spectroscopy; Principles and Chemical Applications, 8th Ed. S. Chand \& Company, Ram Nagar, New Delhi,1997.

[23] WINGBORG.N.: Increasing the tensile strength of HTPB with different isocyanates and chain extenders, Polymer Testing, 2002, 21, pp.283-287.

Received: 27.03.2015. Accepted: 10.08.2015. 


\title{
Uticaj 1,4-butandiola na karakteristike gorivno-vezivne komponente kompozitnog raketnog goriva na bazi hidroksiterminiranog poli(butadiena)
}

\begin{abstract}
1,4-butandiol, kao produživač lanaca, korišćen je za izradu sastava gorivno-vezivne komponente kompozitnog raketnog goriva na bazi hidroksiterminiranog poli(butadiena). Kao umreživači korišćeni su izoforondiizocijanat (IPDI) $i$ toluendiizocijanat (TDI). Ispitivane su karakteristike polimerne mrě̌e kao i mehaničke karakteristike dobijenog sistema. Određeni su parametri nastale polimerne mreže, sol-gel sadržaj i gustina umreženosti. Izvršena je korelacija ovih parametara i mehaničkih karakteristika dobijenih ispitivanjem jednoosne zavisnosti napon-deformacija. Rezultati dobijeni diferencijalnom skenirajućom kalorimetrijom pokazali su da sadržaj 1,4-butandiola ne utiče na vrednost temperature ostakljivanja, dok vrednosti jednoosnih mehaničkih karakteristika zavise od gustine umreženosti ispitivanih sastava gorivnovezivne komponente.
\end{abstract}

Ključne reči: butandiol, hidroksiterminirani polibutadien, kompozitno raketno gorivo, gorivno-vezivna komponenta, mehaničke karakteristike.

\section{Influence du butanediol 1,4 sur les caractéristiques de la composante propergol - liant du propergol composite à la base de poly (butadiène) hydroxyle terminé}

\begin{abstract}
On a utilisé butanediol 1,4 comme prolongateur des chaînes pour la fabrication de la composante propergol- liant, composante du propergol composite à la base du poly(butadiène) hydroxyle terminé. Comme les durcisseurs on a employé isophorone diisocyanate (IPDI) et toluène diisocyanate. Les caractéristiques du réseau polymère ainsi que les propriétés mécaniques du système obtenu ont été examinées. On a déterminé les paramètres du réseau polymère réalisé, contenu sol gel et la densité du durcissement. On a établi la corrélation des ces paramètres et les propriétés mécaniques obtenus par l'examen de la dépendance uniaxe de la tension - déformation. Les résultats obtenus par la calorimétrie différentielle scannée ont démontré que le contenu de butanediol 1,4 ne faisait pas l'influence sur la valeur de température de vitrification alors que les valeurs de propriétés mécaniques uniaxes étaient dépendantes de la densité du durcissement des compositions propergol liant de la composante examinée.
\end{abstract}

Mots clés: butanediol, poly(butadiène) hydroxyle terminé, propergol composite, composante propergol-liant, caractéristiques mécaniques.

\section{Влияние 1,4-бутандиола на характеристики топливно- связующих компонентов композитных ракетных топлив на основе гидрокситерминированного поли (бутадиена)}

\begin{abstract}
1,4-бутандиол в качестве удлинителя цепи был использован для изготовления состава топливно-связующей компоненты композитного ракетного топлива на основе гидрокситерминированного поли(бутадиена). В роли агентов использованы изофорондиизоцианат (ИФДИ) и толуолдиизоцианат (ТДИ). Мы исследовали характеристики полимерных сеток, а в том числе и механических свойств полученной системы. Здесь определяются параметры полученной полимерной сети по содержанию золь-гель и плотность сшивки. Здесь выполнена корреляция этих параметров и механических характеристик, полученных исследованием одноосной зависимости напряжениедеформация. Результаты полученные методом дифференциальной сканирующей калориметрией показали, что содержание 1,4-бутандиола не влияет на значение температуры стеклования, в то время как значения одноосных механических характеристик зависят от плотности сшивки испытанных составов топливно-связующей компоненты.
\end{abstract}

Ключевые слова: бутандиол, гидрокситерминированный полибутадиен, композитное ракетное топливо, топливносвязующие компоненты, механические характеристики. 